\title{
Isolated Bilateral First-Rib Fractures
}

\author{
Izole Bilateral Birinci Kosta Kırığı
}

\author{
Hüseyin Çebiçci', Murat Yücel², Oğuzhan Bol', Nurullah Günay' \\ 'Department of Emergency Medicine, Kayseri Training and Research Hospital, Kayseri, Turkey \\ ${ }^{2}$ Department of Emergency Medicine, Sakarya University Faculty of Medicine, Sakarya, Turkey
}

\section{ABSTRACT}

Introduction: Bilateral fractures of the first rib are extremely rare and usually associated with either multiple rib fractures or serious traumatic injuries. In many cases, first rib fracture is related to serious trauma of the intrathoracic, head, and cervical spine, including neurovascular injuries. We present a case report of isolated bilateral first rib resulting from fracture following falling down from approximately 3 meters in height.

Case Report: A 52-year-old woman, with Glasgow coma scale score 15, fell down 2 hours ago and was admitted to the emergency department. Patient's vital signs were stable. Breath and heart sounds and pulse examinations in the bilateral carotid arteries and upper extremities were not determined to be aberrant. The cervical spine radiographic figures were obtained as intact; however, the bilateral first ribs were fractured by direct radiography and thoracal computerized tomography. There were no other pathological findings related to the patient.

Conclusion: The first rib is deeply placed and protected by the shoulder girdle and muscles, the fracture of which remains the rarest of all rib fractures. We know that potential life-threatening injuries occur with only first-rib fracture; so, we think that the potential risk of that trauma is too high in the case of bilateral firstrib fractures. Our patient was fortunate.

Keywords: Bilateral rib fractures, isolated fracture of the first rib Received: 25.11.2012 Accepted:20.03.2013

\section{ÖZET}

Giriş: Bilateral birinci kosta kırı̆̆ı son derece nadirdir ve genellikle birden fazla kosta kırığı veya ciddi travmatik yaralanmalarla birliktedir. Birçok vakada birinci kosta kırığı intratorasik ciddi yaralanmalarla, ciddi nörovasküler yaralanmaları içeren baş ve sevikal vertebra travmalarıyla ilişkilidir. Biz yaklaşık 3 metre yüksekten düşen ve izole olarak bilateral birinci kostası kırılan bir olgu sunuyoruz.

Olgu Sunumu: Elli iki yaşında kadın, acile gelmeden 2 saat önce düşmüş, glasgow koma skoru $15^{\prime}$ di. Hastanın vital bulguları stabildi. Akciğer, kalp sesleri, bilateral üst ekstremite ve karotis arter nabız muayenelerinde bir anormallik tespit edilmedi. Servikal vertebra radyografik olarak intaktı, ancak direkt radyografi ve torakal bilgisayarlı tomografide bilateral birinci kosta kırığı mevcuttu. Hastada başka herhangi bir patolojik bulguya rastlanılmadı.

Sonuç: Birinci kosta derin yerleşimlidir, omuz kuşağı ve kaslar tarafından korunur, kırılması tüm kosta kırıkları içerisinde nadirdir. Biliyoruz ki birinci kosta kırı̆̆ı hayatı tehdit eden yaralanmalarla beraberdir, bu yüzden bilateral kosta kırığı olan vakalarda potansiyel riskin yüksek olduğunu düşünüyoruz. Bizim hastamız şanslıydı.

Anahtar Kelimeler: Bilateral kosta kırığı, izole birinci kosta kırığı

Geliş Tarihi: 25.11.2012 Kabul Tarihi: 20.03.2013

\section{Introduction}

Bilateral fractures of the first rib are extremely rare and usually associated with either multiple rib fractures or serious traumatic injuries (1-5). In many cases, traumatic fractures of the first rib occur together with serious intrathoracic, head, and cervical spine (C-spine) as well neurovascular injuries (4). Violent muscular contraction and chronic stress are the nontraumatic causes (1).

We present a case of isolated bilateral first rib fracture because of falling down from 3 meters in height.

\section{Case Report}

A 52-year-old woman who fell down 2 hours ago was admitted to the emergency department. On arrival in the Emergency Department, her Glasgow Coma Scale score was 15. Her vital signs included blood pressure of 140/80 mm Hg, pulse rate 92 
beats/min, respiratory rate 16 breaths/min, and oxygen saturation 96\% without oxygen supply. Skin abrasions were seen between the neck and right shoulder with inspection. The patient was suffering from pain with palpation of the lower cervical spine in the physical examination, and her complaint was increasing by lifting her right shoulder. She had normal pulses in the bilateral carotid arteries and upper extremities as well as normal breath and heart sounds on listening to the chest with a stethoscope. The assessment of the cranial nerve was normal. The C-spine radiographies were normal, but isolated, bilateral first-rib fractures were established on the chest radiograph (Fig. 1) and thoracal computerized tomography (Fig. 2). There was no other radiologic finding. She was managed conservatively at the thoracic surgery service and discharged 5 days after admission without any complications.

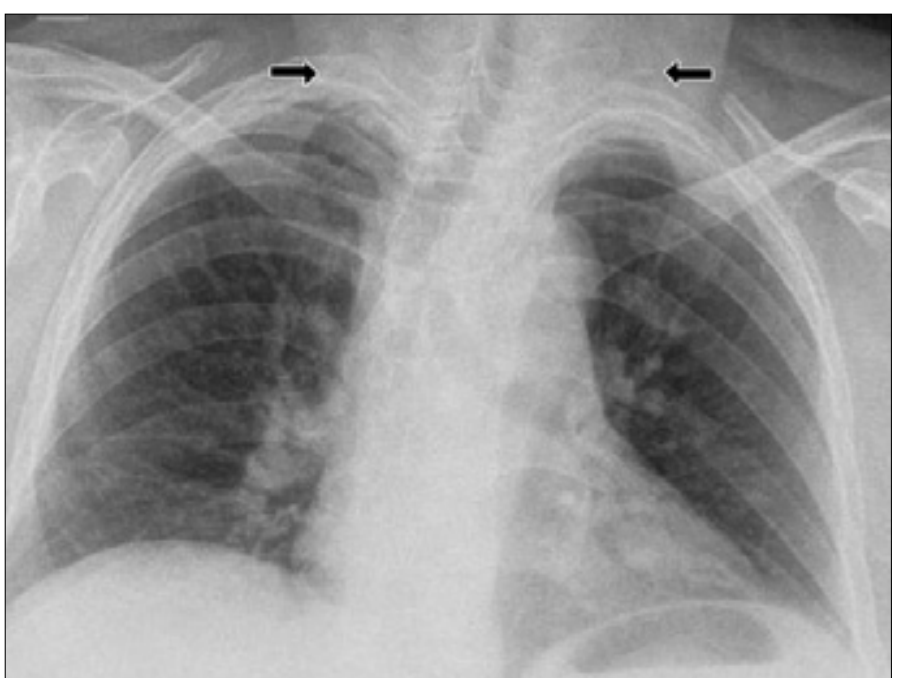

Figure 1. Chest radiograph showing bilateral first-rib fractures

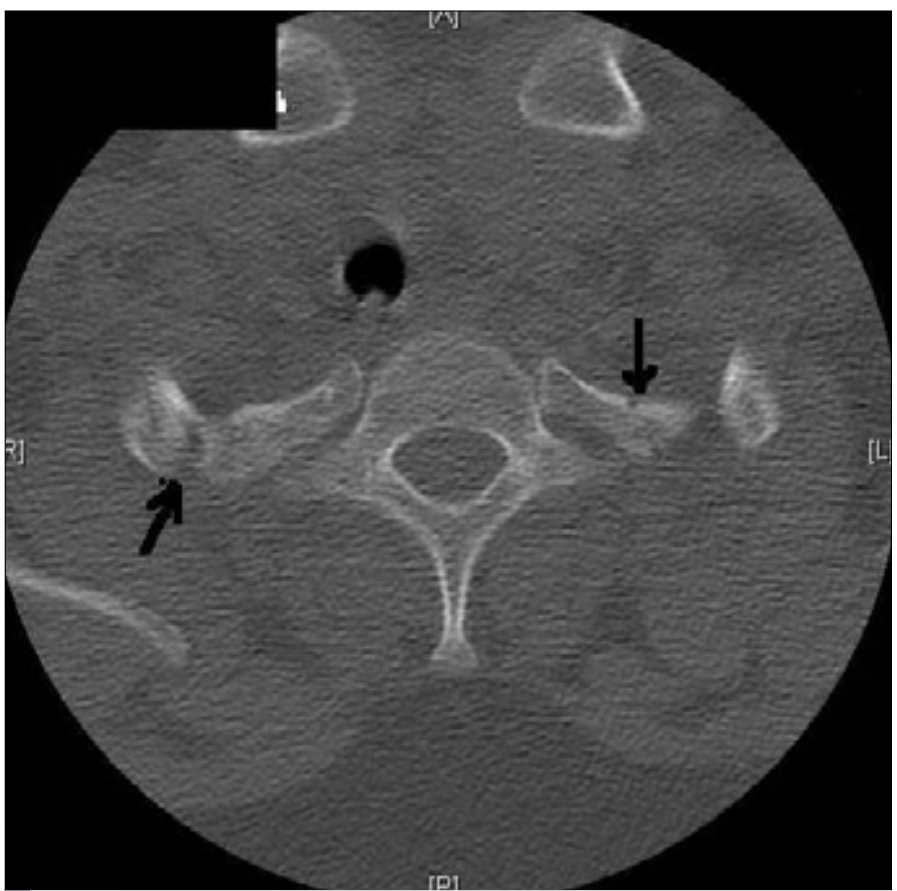

Figure 2. Thoracal CT showing bilateral first-rib fractures

\section{Discussion}

The first rib is deeply placed and protected by the shoulder girdle and muscles, and fracture of the first rib remains the rarest of all rib fractures (4). In many cases, traumatic fractures of the first rib occur together with serious intrathoracic, head, and C-spine as well neurovascular injuries (4). The incidence of first-rib fracture could hardly be defined due to its rarity but has been estimated at between $0.001 \%$ and $0.005 \%$ in reviewing chest radiographies of healthy young Navy personnel and in patients who were screened for tuberculosis (4). The weakest point of the first rib is at the groove for the subclavian artery, which is also the thinnest portion of the first rib $(4,6)$.

The mechanism of first-rib injury in motor vehicle accidents seems to be a violent contraction of the scalene muscles brought on by the sudden forward movement of the head and neck $(4,7)$. Associated complications include delayed subclavian vessel thrombosis, aortic aneurysm, tracheobronchial fistula, and thoracic outlet syndrome (4). Horner's syndrome also has been reported to result from first-rib fracture $(4,5,8,9)$.

\section{Conclusion}

Accurate diagnosis of first-rib fracture can often be made by chest radiography. Recognition of potentially life-threatening injuries associated with first-rib fractures is essential.

Hasta Onamı: Yazılı hasta onamı bu çalışmaya katılan hastadan alınmıştır.

Hakem Değerlendirmesi: Dış bağımsız.

Yazar Katkıları: Fikir - H.Ç.; Tasarım - H.Ç.; Denetleme N.G.; Kaynaklar - H.Ç., M.Y.; Malzemeler - O.B.; Veri toplanması ve/veya işlemesi - H.Ç., O.B.; Analiz ve/veya yorum - H.Ç., M.Y.; Literatür taraması - H.Ç., M.Y.; Yazıyı yazan - H.Ç., M.Y.; Eleştirel İnceleme - N.G., O.B.

Çıkar Çatışması: Yazarlar herhangi bir çıkar çatışması bildirmemişlerdir.

Finansal Destek: Yazarlar bu çalışma için finansal destek almadıklarını beyan etmişlerdir.

Informed Consent: Written informed consent was obtained from the patient who participated in this study.

Peer-review: Externally peer-reviewed.

Author Contributions: Concept - H.Ç.; Design - H.Ç.; Supervision - N.G.; Funding H.Ç., M.Y.; Materials - O.B.; Data Collection and/or Processing - H.Ç., O.B.; Analysis and/or Interpretation - H.Ç., M.Y.; Literature Review H.C.., M.Y.; Writing - H.C.., M.Y.; Critical Review N.G., O.B.

Conflict of Interest: No conflict of interest was declared by the authors.

Financial Disclosure: The authors declared that this study has received no financial support. 


\section{References}

1. Qureshi T, Mander BJ, Wishart GC. Isolated bilateral first rib fractures-an unusual sequel of whiplash injury. Injury 1998 Jun; 29: 397-8. [CrossRef]

2. Dwivedi SC, Varma AN. Bilateral fracture of the first ribs. J Trauma. 1983; 23: 538. [CrossRef]

3. Villa I, Pessina R, Bonacina P, Gaetani G. Traumatic simultaneous bilateral fracture of the first rib. Chir Ital. 1985; 37: 194-7.

4. Lee SJ, Chu SJ, Tsai SH. Isolated bilateral first-rib fractures. J Emerg Med 2010; 39: 204-5. [CrossRef]

5. Ozel SK, Kazez A. Horner syndrome due to first rib fracture after major thoracic trauma. J Pediatr Surg 2005; 40: e17-9. [CrossRef]
6. Colosimo AJ, Byrne E, Heidt RS, Jr, Carlonas RL, Wyatt H. Acute traumatic first-rib fracture in the contact athlete: a case report. Am J Sports Med 2004; 32: 1310-2. [CrossRef]

7. Stoneham MD. Bilateral first rib fractures associated with driver's air bag inflation: case report and implications for surgery. Eur J Emerg Med 1995; 2: 60-2. [CrossRef]

8. Hassen AN, Ballester J, Slater N. Bilateral first rib fractures associated with Horner's syndrome. Injury 2000; 31: 273-4. [CrossRef]

9. Ozel SK, Kazez A. Horner's syndrome secondary to tube thoracostomy. Turk J Pediatr 2004; 46: 189-90. 